\title{
EGG PRODUCTION AND HATCHABILITY OF LOCAL DUCKS UNDER SEMI INTENSIVE $V S$ EXTENSIVE MANAGEMENTS
}

\author{
P. Widiyaningrum, Lisdiana and N.R. Utami \\ Department of Biology, Faculty of Mathematics and Natural Sciences, \\ Semarang State University, \\ Jl. Raya Sekaran Gunungpati, Semarang 50229 - Indonesia \\ Corresponding E-mail: wiwiedeka@yahoo.co.id
}

Received May 18, 2015; Accepted April 09, 2016

\begin{abstract}
ABSTRAK
Tujuan penelitian untuk membandingkan produksi dan daya tetas telur itik lokal yang dipelihara peternak dalam dua cara berbeda, yaitu semi intensif dan ekstensif. Penelitian menggunakan rancangan klasifikasi satu arah terdiri dari 2 perlakuan, setiap perlakuan terdiri dari 15 jantan dan 120 ekor betina (nisbah perkawinan 1:8). Umur itik antara 13-14 bulan. Pencatatan jumlah produksi telur dilakukan selama tiga minggu. Telur sebanyak 300 butir diseleksi dari masing-masing perlakuan untuk ditetaskan dan diteliti fertilitas, dan daya tetasnya. Fertilitas dihitung pada hari ke 4 penetasan dengan menggunakan egg candler. Hasil pengamatan produksi telur, berat telur, fertilitas dan daya tetas dianalisis menggunakan uji beda unpaired two sample Student's t-test. Hasil penelitian menunjukkan rata-rata berat telur, fertilitas dan daya tetas tidak berbeda pada kedua sistem pemeliharaan, tetapi total produksi telur pada pemeliharaan semi intensif nyata lebih tinggi $(\mathrm{P}<0,05)$ dari pada sistem ekstensif. Perbedaan total produksi telur pada kedua perlakuan sebesar $12,3 \%$. Kesimpulannya, sistem semi intensif meningkatkan jumlah telur yang dihasilkan, tetapi tidak berbeda pada rata-rata bobot, fertilitas dan daya tetas telur.
\end{abstract}

Kata kunci : itik lokal, semi intensif, ekstensif, produksi, daya tetas

\begin{abstract}
The study aimed to compare the egg production and hatchability of local ducks under different management systems, namely semi-intensive and extensive. The research conducted was an experimental one-way classification with two treatments. Each treatment used 15 male and 120 females (mating ratio 1:8), and ducks aged 13-14 months. Eggs production was recorded during three weeks period. About 300 eggs were selected from each treatment to be hatched. Fertility was observed at $4^{\text {th }}$ days of hatching process using egg candler. Data of eggs production, eggs weight, fertility, and hatchability were analyzed using unpaired two sample Student's t-test. The results showed that average of egg weight, fertility and hatchability were not different under two management system, but egg production in the semi-intensive maintenance was significantly higher $(\mathrm{P}<0.05)$ than those in the extensive system. Egg production in the semi-intensive was $12.3 \%$ higher than those in the extensive. In conclusion, the semi-intensive system that is applied in this study the number of eggs production but did not affect the average of egg weight, fertility and hatchability.
\end{abstract}

Keywords : local duck, semi intensive system, extensive system, egg production, hatchability 


\section{INTRODUCTION}

Most rural farmers are raising ducks in an extensive system and less in an intensive management. Generally, the extensive system is performed by herding ducks to find locations of feed sources such as rice field or swampy areas. This system is the simplest method and needs small capital input because most farmers are raising ducks as part of the mixed farm. This is called free range system (Meulen and Dikken, 2004). Zhang et al. (2009) stated that rice-duck farming (in China) was one of the traditional systems, but currently and gradually popularized as ecological farming techniques for paddy rice production, because the research showed that $84 \%$ of the weed biomass was inhibited by duck activities in the rice field.

In Indonesia, duck plays as a source of food and income for rural communities. Unfortunately, most farmers are raising it in a traditional method, which is characterized by low productivity and the availability of feeds depended on the season, so the egg products, meat ${ }_{2}$ and grain prices are fluctuated (Salendu, 2012). Therefore, the growth rate and productivity of eggs are not promising compared with the results reported on ducks maintenance in intensive or semi-intensive (Etuk et al., 2006).

A study by Center for Indonesian Veterinary Analytical Studies (2006) showed that $86 \%$ of total respondents (as the highest percentages of farmers interviewed) applied the extensive system with little or no feed supplementation. Hence, growth rate and egg productivity were lower compared to other research reports where intensive or semi-intensive management systems were used (Etuk et al., 2006). In fact, especially in Java and Bali, duck is traditionally raised in rice fields that have natural food of $22.5 \%$. The low egg production is due to lack of food, so it is not sufficient for the growth need and egg production. This fact is still prevalent in some agricultural areas, which indicates that it is a cultural system that is not easily eliminated. An early observation in Wedung district, Demak Regency, revealed that ducks reared in traditional system (herding system) had low productivity because herding is usually done far from the village, causing ducks took more energy to do the activity and produce eggs. Moreover, supplemental feeding is not routinely given causing lack of nutrition (unpublished report).

Technically, farmers are not willing to switch to the intensive systems because the intensive system is more costly. Yet, encouraging the farmers to switch to semi-intensive is quite possible to be conducted. Under semi-intensive system, ducks still can be grazed sometimes, especially after paddy harvested, but the additional food is also given for a better egg productions. The study aimed to compare the egg production and hatchability of local ducks under different management systems, extensive versus intensive.

\section{MATERIALS AND METHODS}

\section{Animal and Feeding Management}

The study was carried out for 3 months (July-September 2013) in Wedung district, Demak Regency-Central Java province. The research was an experimental one-way classification with two treatments. Each treatment was performed for 15 male and 20 females (mating ratio 1:8) ducks aged 13-14 months. The laying ducks were around 13-14 months old. Under the semiintensive system, the farmers applied fully feeding system without herding but still provide a free-range area for the duck. Ducks are free ranging, resting and swimming in the pond and around the confinement, so they felt like living in a natural environment. The ducks feed was composed of rice bran, parched rice, fish byproducts and commercial concentrate having ratio of 40:30:20:10 as farmers usually do. In the semi-intensive group, the food was given twice, in the morning and afternoon, an average of 150 $\mathrm{g} /$ duck/day. Proximate analysis of duck ration are shown in Table 1. In the extensive system, the farmers applied the herding system, while ducks were given $50 \%$ additional food with the same composition, only at night after herding as farmers usually do. At night, the flock is returned to a confinement (a bamboo pen), where eggs are laid during the night. During the day, a flock of ducks, are allowed to search for feed in harvested rice fields and other areas where the feed is plentiful. The desirable mating ratio for good fertility and hatchability for ducks is 1:8.

\section{Parameters Measured and Data Analysis}

Parameters observed in this study were egg production, egg weight (g), fertility (\%) and hatchability (\%). Egg production was recorded during three weeks. Furthermore, 300 selected eggs were used for each treatment. The candling of eggs was done at $4^{\text {th }}$ days of incubation using 
Table 1. Proximate Analysis of Duck Ration under Semi Intensive Management

\begin{tabular}{lcccc}
\hline \multirow{2}{*}{ Component } & \multicolumn{3}{c}{ Ration } & \multirow{2}{*}{ Average (\%) } \\
\cline { 2 - 4 } & 1 & 2 & 3 & 12.1047 \\
\hline Water (\%) & 11.6591 & 12.5660 & 12.0889 & 23.1247 \\
Ash (\%) & 20.7023 & 24.7708 & 23.9011 & 10.8760 \\
Crude fat (\%) & 10.4900 & 11.2677 & 10.8703 & 10.7360 \\
Crude fiber (\%) & 10.8158 & 10.1820 & 11.2102 & 20.8821 \\
Crude protein (\%) & 21.0043 & 20.3116 & 21.3304 & 3106.8 \\
Gross energy (Kcal) & 3106.5 & 3096.1 & 3117.7 & \\
\hline
\end{tabular}

an electrical candler to sort out the clean eggs and dead embryos. The eggs with developed germinal disc were considered as fertile. Fertility percent of eggs was calculated as a total number of fertile eggs divided by a total number of eggs multiplied by 100 . Hatchability was calculated after an incubation period of 28 days. Data of eggs production, eggs weight, fertility, and hatchability were analyzed using unpaired two sample Student's t-test in SPSS program (McDonald, 2008).

\section{RESULTS AND DISCUSSION}

\section{Egg Production}

The data of average egg production is shown in Figure 1. Eggs production under the semiintensive system ranged from $60 \%-82.5 \%$, while eggs production under the extensive system were $55-67.5 \%$. Eggs production in the semi-intensive system was significantly higher $(\mathrm{P}<0.05)$ than those in the extensive system, with a difference of about $12.3 \%$. There are many factors that influence the difference in eggs production. Eggs production is influenced by food, genetic, nutrition, balanced energy-protein, egg-laying period and the moulting period (Purba et al., 2005; Pingel, 2009). Stress due to the short period of adaptation when entering a new cage will also affect eggs production (Komarudin et al., 2008). In this case, the main challenge is how to encourage farmers to shift toward a more intensive and efficient production system, and to help them overcome problems facing the duck management, such as low-quality of breeding stocks, scarce and unpredictable quality of locally available feedstuff, source of qualified day-old ducklings, and lack of information about the nutrient requirement of ducks. According to Adzitey and Adzitey (2011), under the traditional systems, ducks can scavenge on their own to obtain the necessary nutrients needed for their growth, but if they do not get extra nutrients, the egg production remains low. In an intensive care and nutritional adequacy, ducks are capable of producing eggs up to $80 \%$. Wibowo et al. (2007) revealed that production of eggs and the amount of profit (income over feed cost) obtained in the semi-intensive system maintenance was higher compared to the extensive system. Total mortality in the extensive system was lower compared to semi-intensive and intensive systems while the length of moulting in the intensive and semiintensive systems was shorter compared to the extensive system. The advantages of intensive maintenance are a higher eggs productivity, assured health and safety, and efficient maintenance cost. The average eggs production in the grazing system was $24 \mathrm{eggs} / \mathrm{duck} /$ year while eggs production in intensive maintenance could reach more than $200 \mathrm{egg} / \mathrm{duck} /$ year. In other words, the caged ducks are capable of producing more eggs, more stable with higher quality than the grazing system ducks.

The factors affecting egg production are genetic and environment. Genetic factors are heredity of the parent included earlier sexual maturity, the high intensity of spawning, the percentage of nesting and clutch while the environmental factor is feeding and maintenance (Pingel, 2009; Purba et al, 2005). 


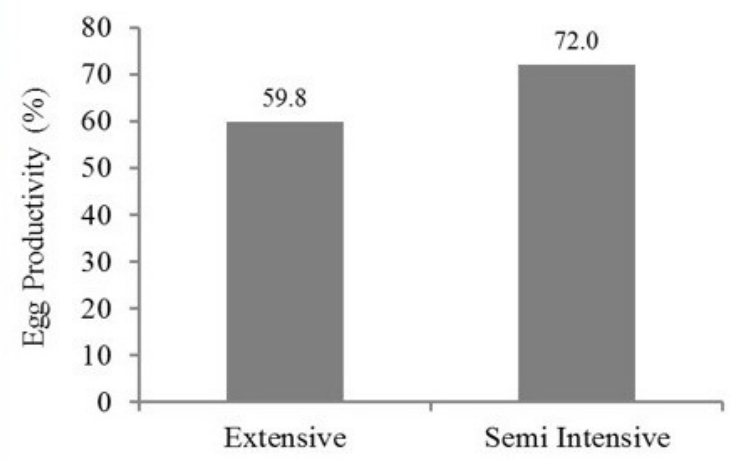

Figure 1. Average Egg Production under Two Management Systems

\section{Egg Weight}

Figure 2 shows that the average egg weight of local duck in the semi-intensive management system was $61.0 \mathrm{~g}$ and that of duck in the extensive system was 59.7 g. Nevertheless, the egg weight of both treatments showed no significant difference. These results were similar to the findings of Juliambarwati et al. (2012) who found eggs weights around 55.89 to $58.36 \mathrm{~g}$ and who calculated eggs production to $58.52 \mathrm{~g}$. Generally, egg weight was influenced by genetic factors, sex, age, nutrition and medicines content in the ration. This fact indicated that duck food provided by the farmer is was sufficient. Under the extensive system, ducks generally eat almost all types of food they find edible, while under semi-intensive system, the ration contains enough nutrients as shown in Table 1. Thus, the duck activity that requires a lot of energy during searching naturally food in the extensive system did not affect the egg weight.

\section{Egg Fertility}

Fertility refers to the percentage of incubated eggs that are fertile. The results showed that average of egg fertility in three replications under extensive system were $82.7 \%$ while semiintensive $83 \%$ (Table 2). This percentage is not significantly different. Thus, raising duck under both management systems did not affect the egg fertility. These results were different from the finding of Datuin and Magpantay (2006) in the Philippines. They stated that the fertility percentage of Mallard ducks raised under modified extensive management system (82.18\%) was significantly higher than those of ducks raised under intensive management system

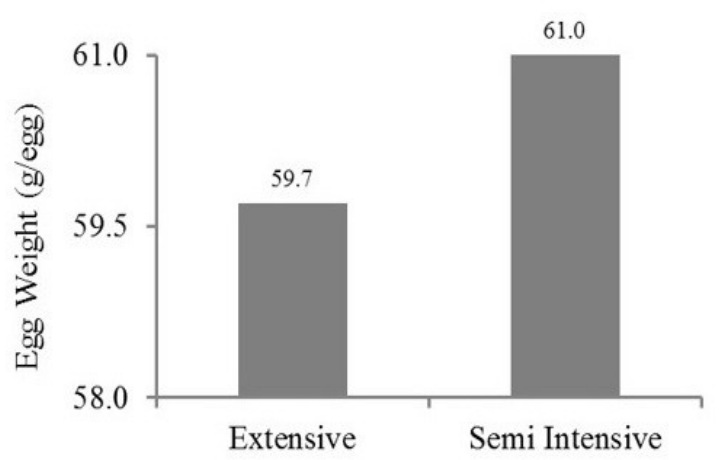

Figure 2. Average Egg weight under Two Management Systems

(76.56\%). There are many factors contributing to the failure of a fertile egg to hatch which include lethal genes, insufficient nutrients in the egg and exposure to conditions that do not meet the needs of the developing embryo (King'ori, 2011). According to Awad (2013), temperature and photoperiod were the two main factors that influence fertility and hatchability in ducks. Fertility and hatchability are usually lower in the summer months, when the temperature rises, compared to the other months and seasons. Specifically, high environmental temperature causes a decrease in the reproduction efficiency of male and female poultry. This decrease is observed during the production of germ cells, the release of the egg, fertilization, and reduction in the strength of the embryo to survive (King'ori, 2011).

\section{Egg Hatchability}

The results showed that the hatching eggs in both management system were not significantly different (Table 2). According to Dewanti et al. (2014), eggs weight had no effect on fertility and hatchability, but egg weight influenced hatching weight. Hassan et al. (2005) conveyed that ideal size egg for being hatched is not too large or too small. In this study, handling and hatching process that applied in both management such as sex ratio, egg weight and environmental conditions were not different, so hatchability was not different too. Temperature and humidity are determining factors in the success of hatching eggs. According to Suryana (2007), an ideal temperature of hatching machine is around $37^{\circ} \mathrm{C}$, and at the end of the hatching process, the humidity should be increased to $85 \%$. He stated that the relative 
Table 2. Egg Fertility and Hatchability (Semi Intensive vs Extensive System)

\begin{tabular}{|c|c|c|c|c|c|c|}
\hline System & Replication & Hatched Eggs & Fertile Egg $\left.{ }^{*}\right)$ & Fertility $\%$ & Hatching Eggs & $\begin{array}{c}\text { Hatchability } \\
\%\end{array}$ \\
\hline \multicolumn{7}{|l|}{ Extensive } \\
\hline & 1 & 100 & 84.0 & 84.0 & 59 & 70.2 \\
\hline & 2 & 100 & 81.0 & 81.0 & 57 & 70.4 \\
\hline & 3 & 100 & 83.0 & 83.0 & 57 & 68.7 \\
\hline & Average & 100 & 82.7 & 82.7 & 57.7 & 69.8 \\
\hline \multicolumn{7}{|c|}{ Semi Intensive } \\
\hline & 1 & 100 & 85.0 & 85.0 & 60 & 70.6 \\
\hline & 2 & 100 & 82.0 & 82.0 & 58 & 70.7 \\
\hline & 3 & 100 & 82.0 & 82.0 & 58 & 70.7 \\
\hline & Average & 100 & 83.0 & 83.0 & 59 & 70.7 \\
\hline
\end{tabular}

*Fertility was observed at the 4 days of hatching process

humidity during the eggs hatching process in the $1-26$ days of age was approximately $79 \%$. The eggs quality can be obtained from good parents with balanced sex ratio. Successful hatching is determined by some factors such as quality of eggs, egg weight, fertility, and hatchability.

\section{CONCLUSION}

The semi-intensive system that was applied in this study increased the number of eggs produced, but it did not affect the average of egg weight, fertility and hatchability. The averages of egg weights in the semi-intensive and extensive system were $59.7 \mathrm{~g}$ and $61 \mathrm{~g}$, respectively; fertility $83 \%$ and $82.7 \%$; while hatchability $70.7 \%$ and $69.7 \%$, respectively. The ducks under the semi-intensive system produce eggs $12.3 \%$ more than ducks in the extensive system. These results can be the positive information for the traditional farmer in Wedung district, thus, it will encourage to change the duck rearing management.

\section{REFERENCES}

Adzitey, F. and S.P. Adzitey. 2011. Duck production: Has a potential to reduce poverty among rural households in Asian communities - A Review. J. World's Poult. Res. 1(1): 7-10
Awad, A.L. 2013. Field study on hatching traits of duck eggs under Egyptian environmental conditions. Egypt Poult. Sci. 33(4):849-863.

Datuin, J.R.M., and V.A. Magpantay. 2013. Egg production performance of mallard ducks raised under intensive and modified extensive management system. Philipp. J. Vet. Anim. Sci. 39 (2): 211-218

Dewanti, R., Yuhan, and Sudiyono. 2014. Pengaruh bobot dan frekuensi pemutaran telur terhadap fertilitas, daya tetas, dan bobot tetas itik lokal. Buletin Peternakan. 38(1):16-20

Etuk, I.F., G.S.Ojewola and S.F. Abasiekong. 2006. Performance of muscovy ducks under three management systems in South Eastern Nigeria. Int. J. Poult. Sci. 5(5):474-476

Hasan, S. M. A., A. Siam, M. E. Mady and A.L. Cartwright. 2005. Physiology, endocrinology, and reproduction: egg storage period and weight effect on hatchability. J. Poult. Sci. 84:1908-1912.

Juliambarwati, M., A. Ratriyanto and A. Hanifa. 2012. Pengaruh penggunaan tepung limbah udang dalam ransum terhadap kualitas telur itik. Sains Peternakan 10 (1): 1-6

King'ori, A.M. 2011. Review of the factors that influence egg fertility and hatchability in poultry. Int. J. Poult. Sci. 10(6): 483-492.

Komarudin, Rukmiasih and P.S. Hardjosworo. 
2008. Performa Produksi Itik berdasarkan Kelompok Bobot Tetas Kecil, Besar dan Campuran. Di dalam: Inovasi Teknologi Mendukung Pengembangan Agribisnis Peternakan Ramah Lingkungan. Prosiding Seminar Nasional Teknologi Peternakan dan Veteriner. Bogor, 11-12 November 2008. p.604-610

McDonald, J.H. 2008. Handbook of Biological Statistics. Sparky House Publishing Baltimore, Maryland. 291p.

Meulen, S.J. and G. den Dikken. 2004. Duck Keeping in the Tropics. Digigrafi, Wageningen, the Netherlands.

Pingel, H. 2009. Waterfowl production for food security. Proceedings, The $4^{\text {th }}$ World Waterfowl Conference. Thrissur, India, 1113 November 2009. p.5-15

Purba, M., P.S. Hardjosworo, L.H. Prasetyo and D.R. Ekastuti. 2005. Pola rontok bulu itik Alabio betina dan Mojosari serta hubungannya dengan kadar lemak darah (trigliserida), produksi dan kualitas telur. J. Ilmu Ternak . Vet. 10(2):96-105.

Salendu. A.H.S. 2012. Integrasi ternak Itik-Padi dalam Menunjang Ketahanan Pangan di Sulawesi Utara. Prosiding Seminar Nasional Peternakan Berkelanjutan 4. Jatinangor, 7 November 2012. p.78-83

Suryana. 2007. Prospek dan peluang pengembangan itik Alabio di Kalimantan Selatan. J. Litbang Pertanian 26(3):109-114.

The Center for Indonesian Veterinary Analytical Studies. 2006. Final report : A review of free range duck farming systems in Indonesia and assessment of their implication in the spreading of the highly pathogenic (H5N1) strain of Avian Influenza (HPAI). p. 17-18

Wibowo, B., E. Juarini and Sumanto. 2007. Karakteristik Pola Pembibitan Itik Petelur di Daerah Sentra Produksi. Seminar Nasional Teknologi Peternakan dan Veteriner. Bogor 21-22 Agustus 2007. p. 658-663.

Zhang, J.E., R. Xu, Xin Chen and G. Quan. 2009. Effects of duck activities on a weed community under a transplanted rice-duck farming system in southern ChinaWeed J. Biol. Manag. 9: 250-257 